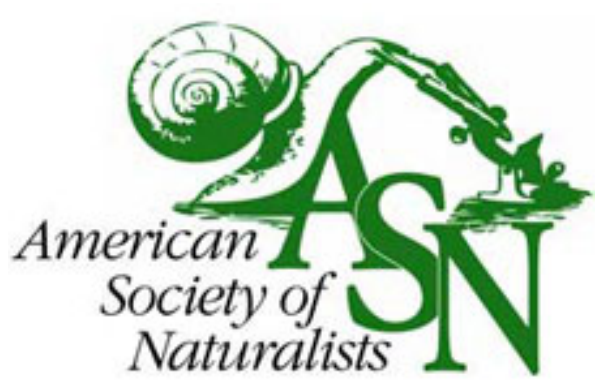

On the Interpretation of Unusual Events in Geologic Records Illustrated by Recent Examples Author(s): Frederic W. Simonds

Source: The American Naturalist, Vol. 34, No. 402 (Jun., 1900), pp. 495-501

Published by: The University of Chicago Press for The American Society of Naturalists

Stable URL: http://www.jstor.org/stable/2453610

Accessed: 11-06-2015 18:11 UTC

Your use of the JSTOR archive indicates your acceptance of the Terms \& Conditions of Use, available at http://www.jstor.org/page/ info/about/policies/terms.jsp

JSTOR is a not-for-profit service that helps scholars, researchers, and students discover, use, and build upon a wide range of content in a trusted digital archive. We use information technology and tools to increase productivity and facilitate new forms of scholarship. For more information about JSTOR, please contact support@jstor.org. 


\title{
ON THE INTERPRETATION OF UNUSUAL EVENTS IN GEOLOGIC RECORDS ILLUSTRATED BY RECENT EXAMPLES. ${ }^{1}$
}

\author{
FREDERIC W. SIMONDS.
}

AN examination of many geologic reports will not fail to show that the working geologist, as a rule, devotes but little time to the interpretation of events, though the most valuable data may be furnished by the very rocks which, as a stratigrapher, he indicates on his map or describes in his notebook. To search out relations of rocks stratigraphically is, of course, one thing; to picture in the mind the conditions that prevailed at the time of their deposition is another and a different thing. But while none will dispute the value of stratigraphic work, the value of interpretation should not be underestimated, for by it we gain our clearest insight into the physical conditions of the past. That it is to a great extent theoretical may be admitted, yet the results of indirect evidence may approximate the truth. In this paper it is my purpose to show that under some conditions, especially when unusual events have been recorded, there is not only difficulty in making the proper interpretation, but even danger that the interpretation may become misleading - a partial truth being, under some circumstances, conducive to positive error.

Throughout the various ages of the earth, as represented by sedimentary deposits, faunas have succeeded faunas, and floras have succeeded floras. At times the exuberance of life must have been great, so numerous are the imbedded remains; but whether numerous or scarce, they are especially useful to the working geologist in that they enable him to recognize strata. As fossils they are figured and described by the paleontologist, who views them mainly from a biologic standpoint. They also

\footnotetext{
1 Read before Section E, Geology and Geography, American Association for the Advancement of Science, August 23, r 899 .
} 
furnish valuable data in solving problems of descent and explain to the biologist certain obscure points in the structure of living forms. But they afford evidence of another kind, the value of which is determined by the ability of the observer to make a correct interpretation. They may reveal much concerning the habits of species, whether terrestrial or aquatic, and their habitat; they may give clues to temperature and other details upon which climate depends; they may indicate, if the species be aquatic, the nature of the water, whether fresh, salt, or brackish, whether shallow or deep, whether cold or warm, etc. It is from his knowledge of existing conditions of life and growth that the observer is able to interpret the conditions attendant upon certain characteristic growth of the past : that, for example, bright, clear skies, and pure sea-water, of not too great depth and free from the chilling influence of cold currents, are conducive to a profusion of coral growth ; that alternate exposure to sea and air is satisfactory to mussels and other littoral species; that clams thrive best in the sand and mud banks exposed between the tides. Knowledge of this kind enables the acute observer to gain a certain amount of historical insight, when kindred forms are found in strata, concerning the conditions that have prevailed upon the earth in remote times of which there is left no direct record.

It must be admitted, also, that a correct interpretation involves much evidence other than that afforded by organic remains. The rocks themselves, irrespective of their fossil contents, afford most valuable data respecting the conditions attendant upon their deposition: mud, for instance, indicating turbulent times, erosion and waste of land surfaces, heavy rainfalls, swollen rivers, and flooding; foraminiferal ooze and other fine-grained calcareous matter, deep-sea deposits ; sand and gravel, beach deposits. Data of this kind are not to be ignored; nor are those changes, such as the thickening and thinning of strata, the passage of limestone beds into shale or sandstone, or the reverse, which may indicate that the deposition had taken place near to or far from land masses. The information thus derived is to be woven into the record; it is essential for a complete interpretation. 
As a student of geology I was long ago impressed with the masterly interpretation of the Brier Hill Coal Seam of Ohio as presented in the School of Mines Quarterly (April, I883) by the late Professor Newberry. The plan, it seemed to me, was admirable. First, the facts were given; then, from them, was translated the history. The statement of facts is a matter dependent upon observation; it may be full and minute, or of a more general nature, according to the care and skill of the observer. Facts relative to the occurrence of coal in a certain area may be simply recorded as facts, a plan pursued in many geologic reports, which is eminently proper from an economic standpoint, as it enables the practical man to locate seams, and that is all he desires. But, from the standpoint of pure science, where knowledge is the object to be attained, and not wealth, the point of view is different. The facts must be made to reveal more than the order of succession of strata, the areas covered, the thickness and kinds of rock composing the individual layers; they must be interpreted, and this must be, to a great extent, the work of the imagination, the revivifying of a skeleton by the addition of flesh.

This, the speculative side of geology, if I may so call it, is particularly attractive to some scholars. It cultivates the same faculties, employs the same modes of reasoning, so widely used by the ethnologist, who, from the exhumed remains, ornaments, utensils, from the shell heaps and rude weapons, learns much of the habits - the life - of extinct peoples.

Granted, then, that much must be speculative, and purely so, he is the best interpreter who can bring his imaginary picture nearest in accord with facts. Ultimately, then, the interpretation is resolved into a matter of probability, based upon data furnished by observation, but it is, nevertheless, a creation of the mind. Herein lies one of the greatest difficulties: conceded that the observations have been carefully and properly made, extreme caution must be employed in drawing conclusions, lest, by a mental slip, error and not truth be the result.

As I have already intimated, the proper interpretation of paleontologic evidence, supplemented by the data furnished by the rocks themselves, gives us a somewhat definite idea of the 
climate and other physical conditions of a past age, acquaints us with the habits and habitat of species, whether animals or plants, and elucidates many interesting and intricate points concerning their growth, development, and distribution; in short, it enables us to reanimate and reëstablish that age. But all of this must be done, directly or indirectly, in accordance with the light of the present time. We have, it is true, familiarized ourselves with usual events, yet we know that the unusual does sometimes happen, and if now, why not in the past?

That an unusual event in the paleontologic record, judging entirely from present events, might be a source of considerable difficulty, or of positive error in interpretation, cannot be doubted. Let me illustrate : Some years ago, as the result of a heavy storm, fish in large numbers were thrown ashore in certain localities bordering on the Bay of Fundy. Let us suppose this to be a region of rapid sedimentation and that their remains were quickly entombed. Had this event taken place in another age, and had the sediment afterwards been elevated and lithified, then would these remains have afforded suitable material for interpretation. But what should the translation inclicate? An unusual abundance of fish - conditions favorable to the growth and development of this form of life which had been suddenly interrupted? If that, the whole truth would not be told. By an unusual event, viz., a heavy storm, fish remains that under ordinary circumstances would have been distributed over a wide area are accumulated within a small area, and, further, remains that under normal conditions would have ranged through a considerable space vertically, are limited to a single layer or a few layers of the deposit. Under such conditions the abundance of fish is apparent rather than real. Other interpretations might be made ; that, for instance, owing to an epidemic, fish perished in large numbers ; or, again, that a sudden and great decrease in temperature caused the marked fatality.

It will be seen that while each of the above interpretations appears adequate to account for the phenomenon, none have given the complete truth, though in all the occurrence of an 
umusual event has been recognized. The action of the heavy storm is the truth sought but not brought out.

It is fortunate that as the result of an unusual occurrence witnessed by Dr. Joseph Le Conte a rational explanation can be made of the conditions under which insects may be collected in vast numbers within the confines of a single stratum. As ordinarily interpreted, the contents of such a bed would indicate that this particular form of life existed in greater abundance at the time of its deposition than either before or after; whereas, as shown by Dr. Le Conte, the abundance of insect remains may be due to concentration - a perfectly natural result though brought about by unusual conditions. He says :

"On Lake Superior, at Eagle Harbor, in the summer of I 844, we saw the white sands of the beach blackened with the bodies of insects of many species, but mostly beetles, cast ashore. As many species were here collected in a few days, by Dr. J. L. Le Conte, as could have been collected in as many months in any other place. The insects seem to have flown over the surface of the lake; to have been beaten down by winds and drowned, and then slowly carried shoreward and accumulated in this harbor, and finally cast ashore by winds and waves. A small river emptying into the harbor carried also many beetles and ants. Doubtless," he continues, "at Oeningen, in Miocene times, there was an extensive lake surrounded by dense forests, through which ran a small river emptying into the lake; and the insects drowned in its waters, and the leaves strewed by the winds on its surface, were cast ashore by its waves." 1

Again, at the mouth of the Mackenzie River a vast quantity of driftwood is accumulating at the present time, which Sir Charles Lyell long ago predicted would, at some distant period, form a great deposit of coal. Now this accumulation of vegetable matter is that having its origin in a much warmer and well-wooded region. By the flooding of a great stream it is conveyed to its final resting place, which is a locality both climatically and biologically different - a region of low temperature and scant vegetation. Let us suppose that the buried

1 Elements of Geology, Fourth Edition, p. 534. 
accumulation has become coal. An interpretation that the contained tree-trunks represented the vegetable life of that region would be, in the highest degree, erroneous. The lowly terrestrial plants of the vicinity may have entirely disappeared, or their remains, commingled with those of a forest vegetation, may attract little or no attention. Granted, however, that the alluvial barriers may be discovered, that the true character of the deposit may be determined, still there is an unusual event to be translated, namely, the enormous distance the vegetable matter has been transported. To recognize this may be extremely difficult, if not impossible. During the lapse of time, elevation and folding may have taken place; denudation and erosion may have completely altered the topography of so vast an area of country; parts of the great river basin may have become so widely separated that their continuity would scarcely be suspected. This is not an exaggerated statement; on the contrary, it lies strictly within the limits of possibility. If so, then is the danger of misinterpretation clearly shown.

The flooding of streams, it is said, is often quite destructive of fish life ; the copious sediment contained in the water being an undoubted cause of suffocation. During the recent flood in Texas I saw fish so overcome that they were easily taken by hand. When the waters receded their dead bodies were reported as occurring along the river banks and on the bars. Under such conditions it does not seem improbable that parts of the skeleton, and especially the scales, such as those of the ganoid type, should be borne seaward, and finally deposited in salt water, commingled with marine forms. Had a similar circumstance occurred in other than recent time, and had the remains of marine and fresh-water forms been preserved in the same stratum, then a fine discrimination between animals greatly alike in appearance, and, possibly, not presenting characters admitting of direct relations with the present, becomes necessary on the part of the observer would he make a correct interpretation. And, moreover, this hypothetical statement will serve to emphasize the fact that a knowledge of biology is of prime importance to him who would undertake the interpretation of such a record. 
Cases might be multiplied, but the point I wish to make is apparent: an interpretation of the history recorded in strata is an absolute necessity if we are to picture the past. Recorded facts must be made to reveal unrecorded events. It is only from the conclusions drawn that we can give the picture life; if they be wrong, the picture becomes distorted, perchance a monstrosity. Unusual events now happen, hence our right to believe that they have happened in the past. They are at times shrouded in deep obscurity - hidden, it may be, in a mass of intricate details. Often they are confined to a single locality, but they may affect an unusually large area. However this may be, the greatest care is necessary lest we pass them by unnoticed, and the greatest caution, should they be discovered, lest we misinterpret them. Human speculation does not always admit of proof, but when based upon facts, as it should be in geologic interpretation, it may at least approximate the truth.

University of Texas, Austin, Texas. 